\title{
The Historical Retrospect of an Overlooked Business Opportunity Within the Aerospace Sector
}

\author{
Amir S. Gohardani, Faculty \\ agohardani@westcliff.edu
}

\begin{abstract}
The aerospace sector is a dynamic, highly technology-driven industry with a remarkable societal impact. Partially fueled by air transportation and space exploration, the United States aerospace and defense industry generated 143 billion worth in exports in 2017. In light of conventional marketing and management practices pertaining to product development, traditional, nonadaptive product life-cycle management often falls short in this industry, explicitly under circumstances when the customer experience is neglected on a holistic level. Notably, such an approach could indeed result in overlooked business opportunities and strategic planning inconsistencies. In this paper, a specific overlooked aerospace business opportunity is dissected with objectives to depict the potential existence of secondary markets and to suggest a holistic approach to product life-cycle management.
\end{abstract}




\section{INTRODUCTION}

Product development and market penetration signify convoluted tasks in the aerospace industry. The defense-related nature of the aerospace sector inherently results in the fact that product development no longer remains a purely technology-driven process. In fact, the introduction of new aerospace products in the United States, a global leader of this industry, is commonly done with a variety of legislative facets (Department of State, 2012). One of these sets of regulatory regimes, entitled, International Traffic in Arms Regulations (ITAR), restricts and controls the export of defense and militaryrelated technologies to safeguard U.S. national security and further U.S. foreign policy objectives. Thus, since there is an increasing level of competition between nations who aspire for global aerospace dominance, safeguarding technologies is a rather common practice.

With the legislative nature of the aerospace industry in mind, a short historical study about product development with regards to air transportation is fruitful as a starting point. In the early days of flight, the mere objective was to design a flight-capable, aerial vehicle. Balloons and gliders preceded powered aircraft which essentially had the distinct goal of transporting passengers and cargo from point A to point B (Gohardani, 2011). Over time, more efficient ways of transportation were adopted by the industry as progress in aircraft design including aircraft propulsion took place. Piston engines were replaced by gas turbines and the shape of the aircraft fuselage was modified based on the intended flight regime and operational requirements (Gohardani, 2013). Throughout the years, powered aircraft perpetually found new applications, and today, many are familiar with the concept of unmanned aerial vehicles
(UAVs), more commonly known to the general public as drones.

Despite the false perception that the concept of drones is new, this is not the case at all. In fact, onboard pilotless aircraft were the ideas of individuals like George Cayley, referred to as the father of aviation, and Felix Du Temple, the developer of one of the early powered model planes. With other visionaries like Nikola Tesla, designer and inventor of the radio remote control vehicle torpedo, weighing in, these concepts progressively evolved from simple ideas to functional aerial torpedoes and drones (Gohardani, 2018a).

In subsequent sections, additional insight is provided into UAVs, product development in other industries, and an overlooked business opportunity within the aerospace sector.

\section{Unmanned Aerial Vehicle Technologies: Drone TECHNOLOGIES}

Drones have taken the aerospace sector by storm (Juniper, 2018; Parks \& Kaplan, 2017; Custers, 2016). Today, drones are frequently used in support of educational efforts, search and rescue, public safety, and monitoring. Herein, one needs to distinguish between drones operated by the general public (Juniper, 2018) and devices exclusively operated by members of the armed forces for military applications (Parks \& Kaplan, 2017). In the latter case, there are often distinct guidelines and regulatory frameworks set in place for drone use. Nonetheless, the drone operational regime for the general public has been a different story entirely.

With countless numbers of drone applications and the choice of toy manufacturers to streamline the usage of drones, the regulatory framework for drone usage and operation (Custers, 2016) reluctantly fell behind the product to market penetration points. Moreover, as an abundant 
number of cases are constantly reported in which the drone operations result in the invasion of privacy, and at times, prevent firstresponders from performing their duties (Urness, 2018), the legislative puzzle pieces for prevention of such behaviors are continuously falling into place. One direct measure by the Federal Aviation Administration (FAA) to target the aforementioned shortcomings has been to request that drone operators register their drones. Hitherto more than a million U.S. drone users are recorded in the FAA drone register (Gohardani, 2018c).

\section{Anti-Unmanned Aerial Vehicle Technologies: ANTI-DRONE TECHNOLOGIES}

The drone boom and operational inconsistencies amongst different operators have led to the development of a series of antidrone technologies (Atherton, 2016a; Atherton, 2016b; Atherton, 2016c). An antidrone technology essentially refers to a type of technology that can bring down a flying drone or a drone hovering in the sky. For these specific purposes, many different technologies have been suggested and many others are currently being explored. Consider, for example, a technology where bazookas and rifles deploy nets midair and prevent drone rotors from functioning as originally planned, hence, leading to the downfall of the drone from the sky. Another promising anti-drone concept is the usage of laser beams to freeze a drone midair and safely bringing it down. Antidrone startups and entities are currently developing technologies to protect airports, stadiums, prisons, corporates, and high net worth individuals who are increasingly worried about their privacy and safety (Gohardani, 2018a; Levick, 2018). In short, anti-drone systems and technologies are specifically designed to counter unwarranted intrusions of drones (Gohardani, 2018a).
AN OVERLOOKED BUSINESS OPPORTUNITY

In hindsight, it can readily be established that the anti-drone market was indeed an overlooked business opportunity of the aerospace sector. Although this market is being shaped on an ongoing basis and solely features the infancy of its technologies, the anti-drone market is still estimated to reach a billion dollars within the next decade (Gohardani, 2018a). Within this framework, a valid question to ask is, was it ever possible to predict the dawn of the anti-drone market? In short, the answer to this question is yes. However, in order to shed more light on the process of arriving at this answer, two different approaches are suggested. These approaches serve as historical lessons to widen the horizons for future business cases in which adjacent technologies and emerging markets are considered. It should be emphasized that combining these two approaches would have led to a compelling argument and a solid business case for the exploration of a potential emerging anti-drone market.

\section{APPROACH 1: LESSONS LEARNED FROM OTHER DISCIPLINES}

Comprehensive reviews of different disciplines and estimations of hypothetical technical impacts on society enable new paths for innovation. These relationships are often cause and effect. With the answer key in hand, the argument is in essence that a series of privacy and safety concerns could have been predicted with the rapid emergence of drones in remarkable volumes. If at least a different area unrelated to drones is considered, navigation to the answer becomes even more apparent.

Consider the waste management industry as an example. Waste management refers to all the activities and actions required to manage waste from its inception to its final 
disposal (UNSD, 2018). An industry and market created as a consequence of waste in all forms, whether industrial, biological, household, or those cases where the waste poses a threat to human health, the waste management industry engages in holistic thinking about the life-cycle of products. Even though, product usage undoubtedly has a significant effect on such a cycle, historically, this type of thinking has not always been advocated. In an exemplary case, the shipping industry, one of the global polluters, has operated its ships with business as usual until recently when the International Maritime Organization (IMO) finally ruled for an implementation of the reduction of sulfuric content in shipping fuel (Rathi, 2017). Although the shipping industry only produces $3 \%$ of carbon-dioxide emission, it equally produces $13 \%$ of nitrogen, $15 \%$ of sulfur, and $11 \%$ of particulate emissions. This elucidated case reveals that at times normal technology operations lead to unwanted consequences. In the case of drone usage, the drone application itself in combination with pending legislation on drone operation and usage in addition to negligence by operators, are contributing factors to privacy and safety concerns.

Privacy and security concerns have also emerged with cell phones and smartphones and are still a topic of interest to privacy and security advocates (Agrawal, Gans, \& Goldfardb, 2018). Once again, cell phone usage can bear an impact on safety and privacy. Lessons learned from the communication industry could also have paved the path for a better understanding of how non-regulated access to drones would result in the anti-drone market.

\section{Approach 2: Examining Product Succession}

In marketing, the product life cycle at different stages is well-known. This cycle typically includes four stages: introduction, growth, maturity or stabilization, and decline (Anderson \& Zeithaml, 1984).With the objective, amongst others, to reduce environmental impacts at the end-of-life, the invisible bridge to an aftermarket could become visible if the variety of internal markets to be served had been recognized in the implementation of the new technology, as suggested by Leonard-Barton and Kraus (1985). With the new drone technology for the general public, technological forecasting (Quinn, 1967) would also assist in the identification of adjacent subject areas. Furthermore, if the various stages through which a product is designed would be considered in profound detail, branches to new markets could also have been identified.

Two of the contributing factors leading to overlooked business opportunities in the aerospace sector are incorrect usage of market research (Reinartz, 2012) and challenges of executing state-of-the-art programs (Gohardani, 2018a; Gohardani, 2018b). Nonetheless, if opportunities such as the antidrone market had been identified by the leading actors of the drone market, these companies and entities would have had a unique opportunity to develop anti-drone technologies in concurrence with developing the drone technologies originally. Such a strategic approach would possibly have enabled these actors and entities to capture a larger portion of the anti-drone market share as it was developing. Other advantages associated with this strategic approach would have been that the early developers of antidrone technology could have gotten a head start on a variety of technologies and possibly leverage the information gained from the continuously developing drone technology for the anti-drone industry. 
An emerging field that targets crossdisciplinary topics is denoted as science, technology, and society (STS). Recently, STS (Kumar \& Chubin, 2000; Bauchspies, Croissant \& Restivo, 2005; Williams, 2017) has gained momentum. STS is particularly useful when a need for observation of a chosen topic from multilateral perspectives is identified (Gohardani \& Gohardani, 2016; Gohardani, 2018a). For instance, glancing at the drone industry through STS lenses would, at a minimum, have identified the impact of drones on society. With that level of comprehension, which also encompasses other subject areas such as economics, safety, privacy, and legislation, a baseline for an emerging market such as the anti-drone market possibly could have been established.

For clarification purposes, it should be emphasized that aerospace companies and entities linked to the aerospace sector, still have opportunities to gain market share and capitalize on the anti-drone industry. The missed business opportunity described in this article specifically refers to the missed opportunity by originating drone technology companies and entities which overlooked the emerging anti-drone market and its business potential.

\section{CONCLUSION}

In this paper, the anti-drone market has been identified as a missed business opportunity within the aerospace sector. This market is estimated to reach a billion dollars within the next decade and is becoming increasingly relevant on a daily basis (Gohardani, 2018b). With objectives to prevent the unwarranted intrusion of drones, companies and entities in the anti-drone industry have embarked on a quest to develop technologies with aims to protect airports, stadiums, prisons, corporates, and high net worth individuals who are increasingly worried about their privacy and safety. In hindsight of this missed business opportunity, solely two different approaches, communicated as historical lessons, have been suggested for identification of emerging technology markets. These approaches are by no means allencompassing but serve as navigational guides for approaching emerging markets and pave the path for holistic product lifecycle thinking.

\section{DISCLAIMER}

Any opinions, findings, and conclusions expressed in this journal article are exclusively those of the author only and do not necessarily reflect the views of any organization(s) or entities affiliated with the author. 


\section{REFERENCES}

Agrawal, A., Gans, J., \& Goldfardb, A. (30 May 2018) Google's Al assistant is a reminder that privacy and security are not the same, Harvard Business Review. Retrieved from https://hbr.org/2018/05/googles-ai-assistant-is-areminder-that-privacy-and-security-are-not-the-same

Anderson, C. R., \& Zeithaml, C. P. (1984). Stage of the product life cycle, business strategy, and business performance. The Academy of Management Journal, 27(1), 5-24. Retrieved from https://www.jstor.org/stable/255954

Atheron, K. D. (2016a). DARPA wants a new anti-drone weapon by 2020, Popular Science. Retrieved from https://www.popsci.com/darpa-wants-new-anti-drone-weapon-by-2020

Atheron, K. D. (2016b). SkyWall is a new anti-drone net bazooka for police, Popular Science. Retrieved from https://www.popsci.com/skywall-is-an-anti-drone-net-bazooka

Atheron, K. D. (2016c). American anti-drone rifle deployed in Iraq, Popular Science. Retrieved from https://www.popsci.com/american-anti-drone-rifle-spotted-in-iraq

Bauchspies, W. K., Croissant, J., \& Restivo, S. (2005). Science, technology, and society: A sociological approach. Hoboken, New Jersey: Wiley-Blackwell.

Custers, B. (Ed.). (2016). The future of drone use: Opportunities and threats from ethical and legal perspectives. Amsterdam, Holland: T.M.C. Asser Press.

Department of State - DOS. (2012). ITAR international traffic in arms regulation. Redbike Publishing. Retrieved from http://www.redbikepublishing.com/itar-2

Federal Aviation Administration - FAA (2018). UAS registration - UAS flown under the small UAS rule (part 107), FAA. Retrieved from https://www.faa.gov/uas/getting_started/part_107

Gohardani, A.S. (2011). Challenges of future aircraft propulsion: A review of distributed propulsion technology and its potential application for the all-electric commercial aircraft. Progress in Aerospace Sciences, 47(5), 369391. Retrieved from https://www.sciencedirect.com/science/article/pii/S0376042110000497

Gohardani, A. S. (2013). A synergistic glance at the prospects of distributed propulsion technology and the electric aircraft concept for future unmanned air vehicles and commercial/military aviation. Progress in Aerospace Sciences, 57(1), 25-70. Retrieved from https://www.sciencedirect.com/science/article/pii/S0376042112000735

Gohardani, A. S., \& Gohardani, O. (May 2016). Astronautics in light of science, technology, and society, Space Times Magazine. Retrieved from http://astronautical.org/dev/wp-content/uploads/2016/08/ST55-34-mayaug2016-final-for-web.pdf

Gohardani, A. S. (2018a). Owning the $21^{\text {st }}$ century. Aerospace America. Retrieved from https://aerospaceamerica.aiaa.org/departments/owning-the-21st-century

Gohardani, A. S. (2018b). Rx for the workforce. Aerospace America. Retrieved from https://aerospaceamerica.aiaa.org/departments/rx-for-the-workforce

Gohardani, A. S. (2018c). A year of records. Aerospace America. Retrieved from https://aerospaceamerica.aiaa.org Juniper, A. (2018). The Complete Guide to Drones. London, England: Wellfleet Press.

Kumar, D. D., \& Chubin, D. F. (Eds.). (2000). Science, technology, and society: Education. Heidelberg, Germany: Springer.

Leonard-Barton, D., \& Kraus, W. A. (November 1985). Implementing new technology, Harvard Business Review. Retrieved from https://hbr.org/1985/11/implementing-new-technology

Levick, R. (15 May 2018). Drone industry just beginning to take off. In Forbes. Retrieved from https://www.forbes.com/sites/richardlevick/2018/05/15/drone-industry-just-beginning-to-take-off

Parks, L., \& Kaplan, C. (Eds.). (2017). Life in the age of drone warfare. North Carolina, Durham: Duke University Press Books.

Quinn, J. B. (March 1967) Technological forecasting, Harvard Business Review. Retrieved from https://hbr.org/1967/03/technological-forecasting

Rathi, A. (29 August 2017). One of the world's most polluting industries has two years to clean up-and it's woefully unprepared. In Quartz. Retrieved from https://qz.com/1064658/the-shipping-industry-one-of-the-worldsbiggest-polluters-is-being-forced-to-clean-up-its-dirty-fuel 
Reinartz, W. (30 August 2012). Using market research just for marketing is a missed opportunity, Harvard Business Review. Retrieved from https://hbr.org/2012/08/using-market-research-just-for-marketing

Urness, Z. (27 August 2018). Illegal drone grounds firefighting aircraft on 5,400-acre Terwilliger fire, Salem Statesman Journal. Retrieved from https://www.statesmanjournal.com/story/news/2018/08/27/terwilliger-firecougar-reservoir-illegal-drone-shuts-down-firefighters-5-400-acre/1110570002

United Nations Statistics Division - UNSD. (2018). Environment glossary, Glossary of environment statistics. Retrieved from https://unstats.un.org/unsd/environmentgl

Williams, L. D. A. (2017). Getting undone technology done: Global techno-assemblage and the value chain of invention. Science Technology and Society, 22(1), 38-58. Retrieved from http://journals.sagepub.com/doi/full/10.1177/0971721816682799 